\title{
Teacher Preparedness and Education Personnel Facing the Revitalization of Vocational Secondary Schools
}

\author{
$1^{\text {st }}$ Agus Hery Supadmi Irianti \\ Department of Industrial \\ Universitas Negeri Malang \\ Malang, Indonesia \\ agushery_um52@yahoo.com \\ agus.hery.ft@um.ac.id
}

\author{
$2^{\text {nd }}$ Sri Sulisty orini \\ Department of Dressmaking \\ SMK N 5 Malang \\ Malang, Indonesia \\ sulisty orinisri@gmail.com
}

\author{
$3^{\text {rd }}$ Annis au Nafiah \\ Department of Dressmaking \\ SMK N 5 Malang \\ Malang, Indonesia \\ annisaunafiah@yahoo.com
}

\begin{abstract}
The purpose of the study describes the readiness of teachers and educational personnel in vocational schools and see the difference in the readiness of teachers and education personnel in State vocational schools and private. Type of quantitative research with Independent Sample $T$ Test. and hypothesis testing is done with SPSS (Statistical Product and Service Solution) version 20. Population in this research is State and Private SMK management team at $8 \mathrm{SMK}$ in Malang Indonesia. The result of research: a) There are $50 \%$ teachers and state school education staff ready to face revitalization, the rest is quite ready. b) There is $\mathbf{5 0 \%}$. teachers and school personnel Private schools are ready to face the revitalization, $25 \%$ is ready and $25 \%$ not ready c) there is no difference in readiness between teachers and education personnel state vocational schools with private. Suggestions: a) the principal should arrange a program to improve the quality of teachers and education personnel; b). teachers and educators should have high motivation to improve quality and professionalism independently and not always waiting for the program offered.
\end{abstract}

Keywords- Teacher preparedness and education personnel; revitalization.

\section{INTRODUCTION}

SMK as an educational institution that prepares graduates ready to work. Vocational Secondary Education prioritizes the preparation of students to enter employment and develop professional attitudes. Vocational secondary school (SMK) as a form of vocational education as defined in the elucidation of Article 15 UU Sis diknas No 20 of 2003[17], SMK is a secondary education that prepares students primarily to work in certain areas. Vocational education is part of an educational system that prepares a person to be better able to work with a group of work[13]. Vocational Education can be interpreted as: (a) an integral part of general education, (b) and for effective participation in the world of work, (c) aspects of lifelong learning and preparation for responsible citizenship, (d) instruments to promote sustainable development, (e) methods of facilitating poverty alleviation [16]. In its development there is a process of globalization which also colored the development of education, especially vocational education in Indonesia. Globalization is a social process, or a historical process, or a natural process that will bring all nations and nations in a strongerbond to create a new life order [6]. While states that globalization is the general trend of integrating domestic/ local life into the global community in various fields [1].

The introduction of the ASEAN Economic Commu nity (MEA) in 2015 will have an impact on the flow of freight of services, investment and skilled labor and free flow of capital between countries in the ASEAN region [10] Globalization and industrialization are challenges and opportunities must be utilized by the Indonesian people to be able to live parallel and side by side with the world community. Globalization and industrialization on the one hand open up opportunities to accelerate the pace of development, but on the other hand brings increasingly fierce and sharp competition challenges.

Effective vocational education is education that can produce graduate competencies (learners) in accordance with the requirements of certain occupations / workplace [3]. Vocational education as a special education that has been planned to prepare learners to enter the world of work and develop a professional attitude in the field of vocational. Graduates of vocational education are expected to be productive individuals who can compete in the free market. The United states congress defines vocational education as "vocational education" as "accredited to education" [3]. The background picture above causes SMK Graduates must have strong competitiveness in order to compete in the free market. The development of globalization impact on the development in the world of education, especially Vocational education. Indonsia is a vocational country, some of the traits leading to vocational countries are: SMA (high school) comparis on: SMK (vocational high school) is 30:70 contained in Renstra Long Term 2025 National Education, 2013 about 60 million children 
will become demographic bonus, 42 million SMK graduates have not yet added vocational education graduate at higher education level [30]. Seeing the phenomenon and the impact of globalization is considered necessary to find solutions in the future, then Jokowi launched Presidential Instruction Number. 9 of 2016 on the revitalization of SMK [8]. Revitalization will be directed to the governance of institutions, teachers and educators, the quality of learning and vocational work SMK graduates. Even to revitalize SMK, the time for SMK education will change to 4 and 5 years according to need, and the program of Fashion Skill is one that will be changed to 4 years (Spectrum SMK 2016).

Different conditions in each school will have an impact on the implementation of SMK revitalization. It can not be ignored. The role of teachers and educators SMK become an important thing that must be considered. Through this research, it is hoped that the findings can be obtained to prepare the implementation of SMK Revitalization. Some of the above backgrounds can be formulated the problem is How preparedness Teachers and Public and Private education personnel face revitalization. The purpose of this study is to describe the readiness of teachers and educational personnel in vocational schools and to see differences in readiness of teachers and educational personnel in state vocational schools and private

\section{THEORETICAL BASIS}

\section{A. Vocational High School (SMK)}

Vocational High School (Vocational School) is one of the vocationaleducation institutions that have the task of preparing its students by providing knowledge and skills to work in accordance with competence and skill program, have adaptability and high competitiveness to enter the work field. Vocational education has goals that focus on: (1) preparation for employment, (2) career selection, (3) developing competence, and (4) provision of supportive experiences for the transition of job titles from one position to another other position [2].

While vocational education will also make greater efficiency in the production and improve the ability of young men and women by helping them move from unskilled labor to unskilled labor into industrial skilled workers [4].

\section{B. Teacher Professionalism and Personel Education}

The demand for the competitiveness of the nation, especially students of vocational high school graduates (SMK) is inevitable. In the time of globalization including the enactment of the AEC has had an impact on education in Indonesia. Teachers and educators as part of the process of teaching and learning activities in schools, especially SMK are required to have a high professionalism. Law No. 14 of 2005 mentions that Master is a professional educator whose main task is to educate, teach, guide, direct, train, evaluate and evaluate students in early childhood education through formal education and basic education[16].
The same thing is also explained that the teacher or educator must have academic qualification and competence as a learning agent, physically and mentally healthy, and have the ability to realize the goals of National Education [5]. Teacher competencies are contained in the Law of the Republic of Indonesia Number 14 of 2005 article 8 which includes: (1) pedagogic competence, (2) personality competence, (3) social competence commands, and (4) professional competence gained through professional education[18]. Article 35 Paragraph (1) of the Law of the Republic of Indonesia number 20 of 2003 on the Rice Education System states that national education standards consisting of standard content, process standards, graduate competency standards, educational staff standards, management, financing standards, and educational assessment standards should be improved on a planned and periodic basis [17].

It can be concluded that the professionalism of teachers is always developed according to the times and needs and demands are also always changing. The profession refers to a job or position that demands expertise, responsibility, and loyalty to the profession. A profession theoretically can not be done by just anyone who is not trained or prepared for it [15]. The requirements of professional teachers are (1) have a strong science base in mema hami knowledge in the 21st century, (2) mastery of profession tricks based on research and education praks is and (3) the development of professional capability is a continuous and sustained profession between LPTK and the practice of education[7].

\section{Revitalization of Vocational High School (SMK)}

This revitalization was born due to the rapid development of technology that has a negative impact on education in Indonesia. Some of the existing problems demanded the enactment of SMK revitalization The problems can be described as follows: (a) there are 4,672 SMKs in Indonesia that most still do not meet the expected standards; (b) the number of students of SMK 2.14 Million that every year has increased, especially lately with the movement of "SMK can" and the policy comparis on of SMK: SMA $=70: 30$, then the addition of SMK in various regions become quite significant with no regard quality of input, process and output; (c) open and developed skill programs there are 96 programs and expertise (continuously growing) that are uneven and unsuitable between the existing programs at school and the needs of the business / industry in each region, according to the research which states that : of 329 students that have implemented the Industrial Working Practice, 95 of them $(28,88 \%)$ claimed that the work skill during the implementation of industrial working practice was relevant, 128 students $(38.91 \%)$ claimed that it was quite relevant and 106 students $(32.21 \%)$ claimed it less relevant [11] (d) the low quality of graduates, this can be seen from the national examination results purely a matter of the center (e) low interpreneurial spirit from vocational school, it is evident that vocational graduates still tend to be job seekers rather than create jobs, (f) the condition of teachers who not yet well-established in terms of economics so as to affect the performance and quality of graduates. This is evident that there are still many teachers who 
teach in various places / schools with various subjects that is taught so that the mastery of the material less so paid attention; (g) the quality of teachers are still many who have not met the standard of competence expected, (h) Facilities / infrastructure is still limited and less terstandard. Whereas standardization will affect the quality of graduates.

\section{III.METHOD}

This type of research is quantitative and uses two unrelated samples (Independent Sample T Test) which aims to determine whether or not there is an average difference between two unrelated samples. The level of significance used in this study is 0.05 , and hypothesis testing is done using the help of SPSS program (Statistical Product and Service Solution) version 20. The population in this study is the vocational school management team consisting of: headmaster, deputy head of the curriculum field, deputy head of the facility and infrastructure field, deputy head of the student field, from of 8 schools, divided into 2 groups of public and private schools. The sampling technique used in this study is population sampling. This sampling technique was chosen because of the entire population will be used all as a research sample. Determination of this sample size refers to [14] if the sample is less than 100 then better taken all so that the research is a population study. The research instrument is arranged with two alternative choices on the statement and each statement is assessed using Guttman scale. The data analys is technique uses T test with Statistical Product and Service Solution, version 20, to know the difference of preparedness state of SMK and private of SMK.

\section{V. DATA ANALYSIS}

Data on the readiness of teachers and education personnel The Program of Fashion Skills facing the revitalization of SMK includes 3 groups: (1) teacher preparedness data and education personnel of the State face revitalization, (2) teacher preparedness data and private education personnel in facing revitalization, (3) Data Differences readiness of teachers and public and private education personnel in the face of revitalization. Item questions consist of 10 items of questions with 2 alternative answers using Guttman scale with yes and no answer choices. Answer yes then the score 1 and the answer is not then the score 0 . Item questions include:

- Has the number of teachers met teachers' needs for all subjects in school?

- Is the number of productive teachers appropriate to the number of rombels?

- Is the teacher a productive subject having a certificate according to his or her expertise?

- Does the teacher have a minimum undergraduate academic qualification (S1) or diploma four (D-IV)?

- Do you have a labor as needed?

- Do educational staff have educational qualifications as the school's needs?
- Does the School facilitate ongoing training for teachers?

- Does the School facilitate ongoing training for education personnel?

- Does the School have apprenticeship programs for productive teachers in the industry?

- Are productive Teachers applying for an internship in Industry account for $50 \%$ ?

A. Readiness of teachers and educational personnel state to face Revitalisation

Descriptive data of the readiness of Teachers and Education Personnel in state SMK can be seen in the following table.

TABLE I. T ABULATION DAT A OF TEACHER PREPARATION AND SMK EDUCATION PERSONNEL ST ATE

\begin{tabular}{|l|c|c|c|c|c|c|c|c|c|c|c|c|}
\hline \multirow{2}{*}{ SMK } & \multicolumn{10}{|c|}{ Teacher and education personnel state } \\
\cline { 2 - 14 } & 1 & 2 & 3 & 4 & 5 & 6 & 7 & 8 & 9 & 10 & $\begin{array}{c}\sum \\
\mathrm{f}\end{array}$ & $\%$ \\
\hline N 1 & 1 & 1 & 1 & 1 & 1 & 1 & 1 & 0 & 0 & 1 & 8 & 80 \\
\hline N2 & 1 & 1 & 1 & 1 & 1 & 0 & 0 & 0 & 0 & 0 & 5 & 50 \\
\hline N3 & 1 & 0 & 1 & 1 & 1 & 1 & 1 & 0 & 0 & 0 & 6 & 60 \\
\hline N4 & 1 & 1 & 0 & 1 & 1 & 1 & 1 & 1 & 1 & 1 & 9 & 90 \\
\hline
\end{tabular}

Results tabulation of the data has then calculated the total of its readiness and in the count presentation. After that, it is followed by categorization of readiness about teachers and educational staff are categorized into 3 categories, namely: categories ready, less ready and not ready. Presentation data of the distribution of readiness about teachers and public education personnel can be seen in Table 2 below.

TABLE II. DISTRIBUTION OF TEACHER PREPARATION AND EDUCATION PERSONNEL A STATE VOCATIONAL FACING REVITALIZATION

\begin{tabular}{|c|c|c|c|}
\hline Interval & Category & freq & $\%$ \\
\hline $1-3$ & Not Ready & 0 & 0,00 \\
\hline $4-6$ & Less Ready & 2 & 0,50 \\
\hline $7-9$ & Ready & 2 & 0,50 \\
\hline
\end{tabular}

The graph presentation of teacher preparedness distribution and education personnel State SMK face revitalization can be seen in Fig. 1 below. 


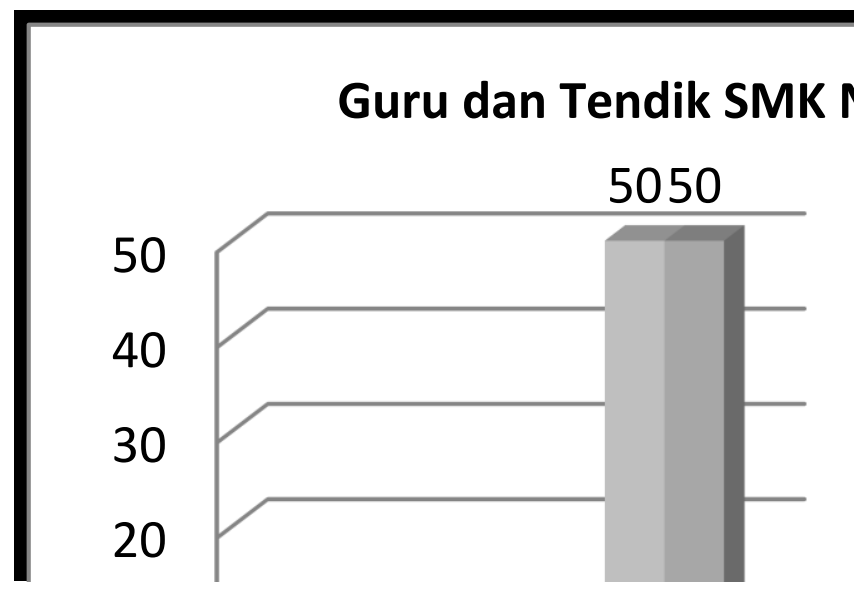

Fig 1 Graph Presentation of Teacher Distribution and Education The Personnel State of SMK

\section{B. Readiness of teachers and educational personnel private}

\section{to face Revitalisation}

Descriptive data of the readiness of Teachers and Education Personnel in Private SMK can be seen in the following table 3 .

TABLE III.

DATA T ABULATION OFTEACHER PREPARATION AND EDUCATION PERSONNEL PRIVATE SMK

\begin{tabular}{|c|c|c|c|c|c|c|c|c|c|c|c|c|}
\hline \multirow{2}{*}{$\begin{array}{c}\text { SMK } \\
\text { Name }\end{array}$} & \multicolumn{10}{|c|}{ Teacher and education personnel Private SMK } \\
\cline { 2 - 14 } & 1 & 2 & 3 & 4 & 5 & 6 & 7 & 8 & 9 & 10 & $\begin{array}{c}\text { f } \\
\text { f }\end{array}$ \\
\hline Private 1 & 1 & 1 & 1 & 1 & 1 & 1 & 1 & 0 & 0 & 0 & 7 & 70 \\
\hline Private 2 & 1 & 1 & 0 & 1 & 1 & 1 & 0 & 1 & 0 & 0 & 6 & 60 \\
\hline Private 3 & 1 & 1 & 1 & 1 & 1 & 1 & 1 & 0 & 0 & 1 & 8 & 80 \\
\hline Private 4 & 0 & 0 & 0 & 0 & 1 & 0 & 0 & 0 & 0 & 0 & 1 & 10 \\
\hline
\end{tabular}

Results tabulation of the data is then calculated total readiness and in count presentation. After that, it is followed by categorization of readiness about teachers and educational staff are categorized into 3 categories, namely: categories ready, less ready and not ready. Presentation data of distribution of readiness about teachers and education personnel can be seen in Table 4 below.

TABLE IV. DISTRIBUTION OF TEACHER PREPARATION AND EDUCATION PERSONNEL A PRIVATE VOCATIONAL FACING REVITALIZATION

\begin{tabular}{|c|c|c|c|}
\hline Interval & Category & Freq & $\%$ \\
\hline $1-3$ & Not Ready & 1 & 0,25 \\
\hline $4-6$ & Less Ready & 1 & 0,25 \\
\hline $7-9$ & Ready & 2 & 0,50 \\
\hline
\end{tabular}

The graph presentation of the distribution of preparedness of teachers and private personnel SMK can be seen in Figure 2 below.

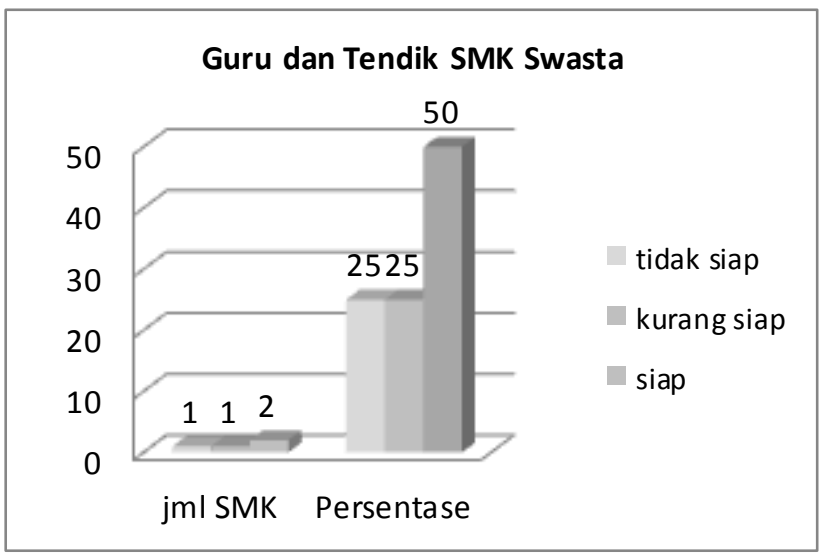

Fig 2 Graph Presentation of Teacher Distribution and Education Personnel Private of SMK

\section{Differences of state and private state vocational preparedness in facing revitalization}

Based on the calculation of Tests using two-tailed test with a significance level of 0.05 , obtained $t$ count (Equal Variance Assumed) 1.704. With 2 side test obtained $\mathrm{T}$ table equal to 2,447 . Since $\mathrm{T}$ calculated $<\mathrm{T}$ table $(1,704<2,447)$ and $\mathrm{P}$ value $(0,139>0,05)$ then $\mathrm{H} 0$ is accepted, Summary Result of Independent Sample T Test Output can be seen in Table 5 and Group Statistics Output can be seen in Table 6 below.

TABLE V.

SUMMARY OF INDEPENDENT SAMPLE OUTPUT T TEST

\begin{tabular}{|c|c|c|c|c|}
\hline \multicolumn{5}{|c|}{ Skor } \\
\hline & & & $\begin{array}{c}\text { Equal } \\
\text { variances } \\
\text { assumed }\end{array}$ & $\begin{array}{c}\text { Equal } \\
\text { varianc } \\
\text { es not } \\
\text { assume } \\
\text { d }\end{array}$ \\
\hline \multirow{2}{*}{$\begin{array}{l}\text { Levene's Test } \\
\text { for Equality } \\
\text { of Variances }\end{array}$} & \multicolumn{2}{|l|}{$\mathrm{F}$} & 1.190 & \\
\hline & \multicolumn{2}{|l|}{ Sig. } & .317 & \\
\hline \multirow{7}{*}{$\begin{array}{l}\text { t-test for } \\
\text { Equality of } \\
\text { Means }\end{array}$} & \multicolumn{2}{|l|}{$\mathrm{T}$} & 1.704 & 1.704 \\
\hline & \multicolumn{2}{|l|}{ Df } & 6 & 5.617 \\
\hline & \multicolumn{2}{|c|}{ Sig. (2-tailed) } & .139 & .143 \\
\hline & \multicolumn{2}{|c|}{ Mean Difference } & 10.000 & 10.000 \\
\hline & \multicolumn{2}{|c|}{ Std. Error Difference } & 5.870 & 5.870 \\
\hline & \multirow{2}{*}{$\begin{array}{l}95 \% \text { Confi } \\
\text { dence Inter } \\
\text { val of the } \\
\text { Difference }\end{array}$} & low & -4.364 & -4.605 \\
\hline & & Upp & 24.364 & 24.605 \\
\hline
\end{tabular}


TABLE VI.

OUTPUT GROUP STATISTICS

\begin{tabular}{|l|r|r|}
\hline & \multicolumn{2}{|c|}{ School Skore } \\
\hline & $\begin{array}{c}\text { The State of } \\
\text { SMK }\end{array}$ & $\begin{array}{c}\text { Private of } \\
\text { SMK }\end{array}$ \\
\hline $\mathrm{N}$ & 4 & 4 \\
\hline Mean & 59.25 & 49.25 \\
\hline Std. Deviation & 9.323 & 7.136 \\
\hline Std. Error Mean & 4.661 & 3.568 \\
\hline
\end{tabular}

The difference test result using $\mathrm{T}$ test shows $\mathrm{T}$ count $<\mathrm{T}$ table $(1,704<2,447)$ and $\mathrm{P}$ value $(0,139>0,05)$ then $\mathrm{H} 0$ is accepted, meaning that there is no difference between teacher preparedness level and education staff of state SMK with average the average readiness of teachers and more private SMK personnel in facing the revitalization of SMK.

\section{DISSCUSSION}

\section{A. Teacher Preparation and SMK Education Personnel in the face of revitalization}

The readiness of teachers and educational staff in SMK Negeri reaches $50 \%$ with enough category ready. This is due to the fact that there is still educational personnel having educational qualifications that are not suitable to the school's needs; schools have not facilitated ongoing training for teachers and education personnel; schools do not have apprenticeship programs for productive teachers in the industry.

The readiness of teachers and educational staff in private SMK reaches $25 \%$ with category not ready. This is due to the fact that there are still a number of teachers who have not met the needs of teachers in all subjects in schools; The number of productive teachers has not been as required by the number of study groups; productive subject teachers not yet certified in accordance with their expertise the school has not facilitated continuous training for teachers and education personnel; schools do not have apprenticeship programs for productive teachers in industry. In addition there are $25 \%$ of enough category ready. This is because schools have not facilitated ongoing training for teachers and education personnel; schools do not have apprenticeship programs for productive teachers in industry

From the above explanation shows that the profeprofesionality of teachers far from what is expected. Government Regulation No. 19 of 2005 on National Education Standard mandates that teachers are professional educators [16]. A professional teacher or personal education must have a minimum academic qualification of undergraduate or diploma four (D4), competency (pedagogic, professional, social, and personality), have educator certificate, physical and spiritual health, and have the ability to realize the purpose of national education [10]. However, the government also took a controversial role with the issuing of policies on the teaching profession that can be carried by anyone as long as it has a certificate of educator (Law No. 14 on teachers and lecturers) and has fulfilled the qualifications of education as mandated by the Regulation of the Minister of National Education No. 16 of 2007 about qualification standards and competence of educators. Teachers who have been taught and are far from professionalism are completed and encouraged to meet the criteria of professional teachers, then just implement Law No. 14. Therefore, to improve the quality of education central targets are addressed is the quality of teachers and the quality of teacher education [21].

\section{B. Differences of public and private state vocational preparedness in Facing Revitalization}

Different test results can be concluded that there is no difference between the average readiness of teachers and educational personnel in state SMK with the average readiness of teachers and education personnel private SMK in the face of the revitalization of SMK. The purpose of no difference here is to have the same problem related to the readiness of teachers and educational personnel in the face of revitalization, but the content of the problems vary. Many challenges have led to the dynamics of teacher professi-onalism, namely the occurrence of a technological revolution. The technological revolution caused the school's role to shift. The world of education should prepare the education system so as not to be left behind by the rapid development of technology. Continuous quality improvement is expected.

\section{CONCLUSIONS}

This study concluded

- There are 50\% teachers and public school education personnel ready to face revitalization, the rest are quite ready

- There are $50 \%$. teachers and school education personnel Private ready to face revitalization, $25 \%$ ready enoughand $25 \%$ not ready

- There is no difference in preparedness between teachers and state SMK with private.

\section{Suggestion}

- The headmaster should arrange a program to improve the quality of teachers and education personnel.

- Teachers and educators should be highly motivated to improve their quality and professionalism independently and not always waiting for the program to offer. 


\section{REFERENCES}

[1] Arfani, R., N., 2044, Golabalisasi Karakteristik \& Implikasinya, (Online), $\quad$ http:/almanar.web.id/.../1.\%20Globalisasi\%20Karakteristik\%20dan\%20Im, Ekonomi Politik Digital Journal Al-Manär Edisi I/2004 Diakses 18 Januari 2012Billet, Stephen (2010). Learning Through Practice, Models, Traditions, Orientation and Approaches, New York : Springer

[2] Billet, Stephen (2010).Learning Through Practice, Models, Traditions, Orientation and Approaches, New York : Springer

[3] Calhoun,C.C. dan Finch, A.V. 1982. Vocational Education.Concep and Operation. Belmot, Wadsworth Publishing Co.

[4] Duvall, E \& Miller, C. M. (1985). Marriage and Family Development 6th ed. New York: Harper \& Row Publisher.

[5] E. Mulyasa, 2007. Menjadi Guru Profesional Menciptakan Pembelajaran Kreatif dan Menyenangkan. Bandung: Remaja Rosda Karya.

[6] Gusbud, 2010, Dampak Globalisasi Ekonomi dan Pengaruh Globalisasi Negatif \& Positif, (Online), www.gusbud.web.id > berita, Diakses 18 Januari 2012

[7] Hasan, Ani M. (2008). Pengembangan Profesionalisme Guru di Abad Pengetahuan (http://re-searchengines.com/ amhasan.html, diakses tanggal 22 September 2017).

[8] Instruksi Presiden (Inpres) Nomor 9 tahun 2016 tentang Revitalisasi Sekolah Menegah Kejuruan Dalam Rangka Peningkatan Kualitas dan Daya Saing Sumber Daya Manusia Indonesia

[9] Irianti A.H. S, 2016. Meningkatakan Profesionalisme Calon Guru Melalui Pendekatan Multi Sinergi. Makalah dipresentasikan pada Konvensi Nasional Pendidikan Indonesia (KONASPI) VIII Tahun2016. 1031-1036. http://seminars. unj.ac.id/konaspi/file/Buku_ Program_KONASPI_VIII_2016.pdf

[10] Irianti,A.H.S. 2015. Menyiapkan Lulusan D3T ata Busana Teknologi Industri Fa-kultas Teknik UM yang Berkualitas Menyongsong Pemberlakuan Masyarakat Ekonomi Asean (MEA) 2015.Makalah disampaikan dalam Semnas PTBB UNY 25 oktober 2015.

[11] Irianti ,A.H.S. 2015. Relevance Of Work Skill Obtained By Students In Industrial Working Practice (Prakerin) In Various Types Of Fashion Industry. In-ternational Journal of Education and Information Studies. ISSN 2277-3169 Volume 5, Number 1 (2015), pp. 1-15.online (http://www.rigouvermentation. comijeisv1n1/).

[12 Muliati,A.M.(2007). Evaluasi Program Pendidikan Sistem Ganda: Suatu Penelitian EvaluatifBerdasarkan Stake's Countenance Model Mengenai Program Pendidikan Sistem Ganda Pada Sebuah SMK di Sulawesi Selatan

[13] Ospina S, Wagner R F 2004, Qualitative Research. Encyclopedia of Leadership.Sage Gouvermentations, <http://ualr.edu>

[14] Ridwan.2007. Metode dan Teknik Menyusun Tesis. Bandung:Alfabet

[15] Supriadi, Dedi. 1999. Mengangkat Citra Guru dan Martabat Guru. Yoyakarta: Adicita Karya Nusa.

[16] Undang-Undang Republik Indonesia no 19 tahun 2005 Tentangandar Nasional StPendidikan Nasional. Jakarta

[17] Undang-Undang Republik Indonesia no 20 tahun 2003 Tentang Sistem Pendidikan Nasional. Jakarta

[18] Undang Undang Republik Indonesia No 14 Tahun 2005 Tentang Guru dan Dosen.

[19] UNESCO, (2006). Identifying and Reaching the Unreached. Education for All Asia and the Pacific.Yin, R K 2011. Qualitative Research from Start to Finish, THE GUILFORD PRESS New York London

[20] Waras Kamdi. 2016.Revitalisasi Pendidikan Kejuruan di Indonesia. Makalah di-sampaikan dalam seminar nasional di Pascasarjana UM tanggal 24 Sep-tember 2016, 2016

[21] Zamroni. 2001. Meningkatkan Mutu Sekolah, Teori, Strategi dan Prosedur. Jakarta: PSAP 